\title{
Pengaruh Jumlah Sinar Ultra Violet Terhadap Penurunan Kandungan Bahan Organik di Dalam Pengolahan Air Gambut yang Dilanjutkan dengan Saringan Pasir Lambat
}

\author{
M. Ma’arij Harfadli ${ }^{1}$ \\ ${ }^{1}$ Teknik Lingkungan, Jurusan Ilmu Kebumian dan Lingkungan, Institut Teknologi Kalimantan, Balikpapan. \\ Email: maarijharfadli@itk.ac.id
}

\begin{abstract}
One of the areas with a complicated drinking are the areas with peat soil. This area has a lot water source, one of treatments for peat water is variation in using the UV light for peat water processing. There is reactors in this research: the UV reactor is made of glass with a 6 liters of reactor volume. The reactor contains 15 watts of 3 ultra violet UV lamps. Processing raw water is done in batch and reactor continuously. The wavelength is $370 \mathrm{~nm}$ which initial absorbance value of 2.045. The optimum time occurs 30 minutes in 3 lamp of UV irradiation with the elimination of organic matters of $36 \mathrm{mg} / 1.73 \%$.

Keywords: Water Peat, absorbance, UV, organic matters.

Abstrak

Salah satu daerah dengan permasalahan air bersih yang cukup rumit adalah daerah dengan tanah berupa lahan gambut. Daerah ini memiliki sumber air yang secara kuantitas cukup banyak, untuk mengolah air gambut menjadi air bersih salah satunya variasi sinar UV pada pengolahan air gambut. Pada penelitian ini menggunakan reaktor yaitu reaktor UV yang terbuat dari kaca dengan volume 6 liter. Reaktor ultra violet berisi 3 lampu uv, 15 watt. Pengolahan air baku dilakukan secara batch dan kontinyu. Berdasarkan hasil penelitian, pada panjang gelombang 370 nm nilai absorbansi awal sebesar 2,045 dan merupakan puncak kurva dari nilai absorbansi. Waktu optimum terjadi pada 3 lampu uv;30 menit dengan penyisihan kandungan organik 36 mg/l;persentase penyisihan sebesar 73.
\end{abstract}

Kata Kunci: Air Gambut, Absorbansi, UV, Zat Organik dan Warna

\section{Pendahuluan}

Salah satu daerah dengan permasalahan air minum yang cukup rumit adalah daerah dengan tanah berupa lahan gambut. Daerah ini memiliki sumber air yang secara kuantitas cukup banyak, bahkan cenderung berlebih sehingga tanahnya pun gembur berair, namun kualitasnya tidak memadai untuk dijadikan sebagai sumber air bersih. Karakteristik menonjol dari air gambut dalam hubungannya dengan kualitas air minum adalah intensitas warnanya tinggi, kandungan organik tinggi, kandungan besi dan mangannya tinggi serta $\mathrm{pH}$ yang rendah antara 3 dan 5 (Badaruddin dan Irianto, 1996).

Air gambut merupakan air dengan karakteristik khusus, berupa kandungan zat organik yang tinggi, warna dengan intensitas tinggi (mencapai 250-700 skala TCU), pH rendah dan kekeruhan rendah (3-6 skala NTU) serta kandungan logam besi dan mangan yang tinggi karena ikatan dengan senyawa organik dalam air gambut tersebut (Rafiq. 1998).

Senyawa lignin merupakan salah satu zat organik alami yang terdapat di dalam air gambut, sehingga akan terjadi korelasi antara penyisihan organik dan warna. Akan tetapi penyisihan warna akan terlihat jauh lebih besar dibandingkan penyisihan organik. Selain lignin kemungkinan terdapat faktor lain penyebab warna di dalam air gambut ini, seperti adanya kation $\mathrm{Ca}, \mathrm{Mg}, \mathrm{Fe}$, dan $\mathrm{Mn}$. Kemungkinan ini didukung secara visualisasi, jika terjadi oksida besi maka air akan berwarna kemerahan dan jika terjadi oksida mangan akan menyebabkan air berwarna coklat kehitaman (Rafiq, 1998).

Zat organik pembentuk gambut sama dengan tumbuhan dalam perbandingan yang berbeda sesuai dengan tingkat pembusukannya. Zat organik ini terdiri dari selulosa, lignin, bitumin, humat, dan lainlain, dimana komposisinya berubah-ubah, seiring dengan proses pembusukan yang terjadi. Unsur-unsur 
pembentuk gambut sebagian besar terdiri dari karbon, hidrogen, oksigen, dan unsur-unsur kecil lainnya seperti Al, Si, Na, S, P, Ca, dan lainya yang berada dalam bentuk terikat seperti CaO, dll (Fitri, 2008).

Masalah yang dihadapi dalam pengolahan air gambut adalah bahwa zat organik yang dikandungnya merupakan zat organik makromolekul yang cukup stabil terhadap degradasi oleh mikroorganisme. Permasalahan pengolahan ini berusaha dipecahkan dengan memanfaatkan degradasi biologis dalam saringan pasir lambat. Namun sebelum disaring dengan media pasir, diperlukan pengolahan pendahuluan untuk memecahkan senyawa organik kompleks di dalam air gambut. Hal ini dikarenakan asam humat merupakan senyawa organik kompleks yang memiliki berat molekul hingga 50.000 (sehingga sukar dipecahkan oleh mikroorganisme). Masalah pemecahan senyawa organik kompleks ini dicoba untuk diatasi dengan sinar ultra violet. Menurut Gmurek, et.al (2015) menyatakan bahwa proses penyinaran serta penyerapan radiasi ultraviolet B dan panjang gelombang sinar tampak oleh senyawa organik merupakan inisiasi serangkaian reaksi fotokimia kompleks yang meningkatkan proses pemurnian air.

Tujuan dari penelitian ini adalah mengetahui pengaruh variasi jumlah sinar ultra violet (neon UV) pada pengolahan air gambut dan kinerja sistem pengolahan yang didasarkan dari nilai efluen yaitu kandungan organik. Sehingga berdasarkan hasil penelitian ini diharapkan dapat menjadi dasar penelitian dan pengembangan teknologi pengolahan air selanjutnya, yang membutuhkan kemampuan proses lebih terpadu, hemat lahan, serta pengoprasian minimal, sehingga dapat memenuhi kebutuhan air di daerah dengan sumber air minum berupa air gambut.

\section{Metode}

Lokasi pengambilan sampel yaitu di Jalan A. Yani Km. 17 Rumah Sakit Sambang Lihum. Kabupaten Banjar, Kalimantan Selatan dapat dilihat pada Gambar 1.

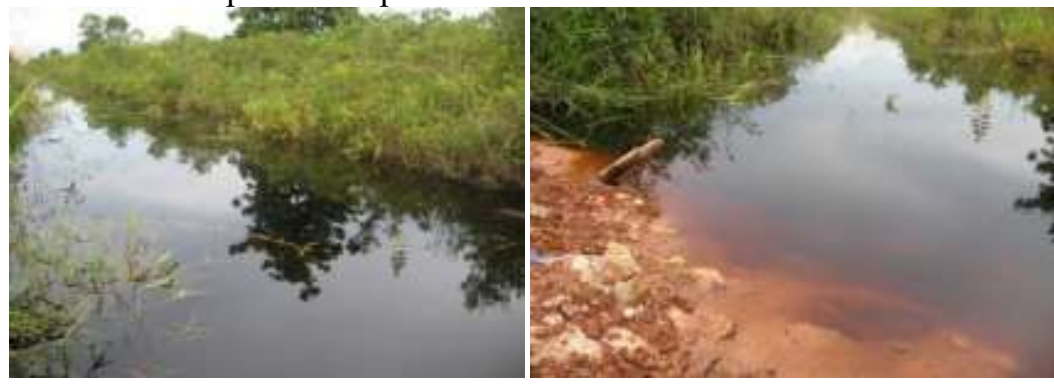

Gambar 1: Lokasi Pengambilan Sampel

Pada penelitian skala laboratorium ini akan dilihat kinerja dari pemaparan sinar ultra violet untuk memutuskan ikatan senyawa organik kompleks yang menyebabkan warna. Penelitian ini terdiri dua bagian. Perlakuan yang pertama yaitu pemeriksaan kualitas air gambut, mengetahui panjang gelombang dengan menganalisis absorbansi senyawa humat menggunakan spektrofotometer UV-vis, melalukan percobaan dengan memberikan variasi jumlah sinar ultra violet dan menentukan detensi penyinaran sinar ultra violet yang optimum terhadap air gambut. Dari tahapan ini, parameter-parameter penelitian diukur kembali agar diketahui kondisi optimum untuk berlangsungnya proses reaksi fotokimia yang diharapkan. Berdasarkan hasil dari perlakuan pertama, dilakukan penyinaran menggunakan sinar UV terhadap air gambut. Dari tahapan ini, parameter-parameter penelitian diukur kembali sehingga diharapkan dapat diketahui penurunan dari parameter tersebut. Sesuai dengan tujuan penelitian ini, penentuan kinerja sistem didasarkan atas efisiensi penyisihan kandungan organik dan warna. Data hasil penelitian dan percobaan laboratorium disajikan dalam bentuk tabel dan grafik.

\section{Hasil dan Pembahasan}

Analisa kualitas air ini dilakukan di Laboratorium PDAM Intan dan BLHD Martapura yang dilaksanakan pada tanggal 27 juli 2011 memberikan hasil yang dapat dilihat pada Tabel 1. 
Tabel 1: Hasil Analisa Kualitas Sampel Air Gambut

\begin{tabular}{|c|c|c|c|c|}
\hline No & Parameter Analisa & Satuan & $\begin{array}{c}\text { Baku } \\
\text { Mutu }\end{array}$ & $\begin{array}{c}\text { Hasil } \\
\text { Analisa }\end{array}$ \\
\hline 1 & Warna & & 10 & 500 \\
\hline 2 & Zat Organik (KMnO4) & $\mathrm{mg} / 1$ & 15 & 136,21 \\
\hline 3 & $\mathrm{Ph}$ & - & $6,5-8,5$ & 4,0 \\
\hline
\end{tabular}

Sumber: Hasil Analisa Laboratorium PDAM Intan dan BLH Banjar

Dari hasil analisa tersebut terlihat bahwa untuk air gambut yang diperoleh menunjukan kandungan organik dan intensitas warna yang tinggi dibandingkan dengan baku mutu baik air bersih maupun air minumberdasarkan Permenkes RI No.492/MENKES/PER/IV/2010. Sehingga untuk air gambut dari daerah Kecematan Gambut yang diambil sebagai sampel penelitian, sangat sesuai dengan kriteria yang diperlukan dari penelitian ini.

Sementara hasil analisa absorbansi dengan spektrofotometer uv-vis model UV-200-RS di laboratorium FKIP MIPA Kimia, Banjarmasin terhadap air gambut yang diperoleh menunjukan pada gelombang di atas $350 \mathrm{~nm}$ senyawa humat baru dapat teridentifikasi, hal ini diyakini pada air gambut memiliki gugusgugus fungsional yang hanya dapat terbaca pada gelombang di atas $200 \mathrm{~nm}$. Panjang gelombang 370 $\mathrm{nm}$ merupakan panjang gelombang puncak tertinggi kurva. Ini berarti bahwa kebutuhan energi untuk transisi elektron bagi molekul-molekul yang terdapat dalam air gambut yaitu dengan panjang gelombang ultra violet sebesar $370 \mathrm{~nm}$. Sehingga dipercaya bahwa adanya gugus kromofor (gugus ini menyerap sinar UV dengan panjang gelombang lebih besar dari $180 \mathrm{~nm}$ ) yang terkandung di dalam air gambut tersebut, mengingat bahwa gugus ini penyebab warna pada senyawa humat (Ismono dalam Rafiq, 1998).Sejalan dengan penelitian Han Kuk, et al (2016) menyatakan bahwa reaksi radikal yang terjadi di air gambut ditunjukan pada panjang gelombang penyinaran ultraviolet sebesar $300 \mathrm{~nm}$.

Penyisihan kadar organik menggunakan sinar ultra violet, hal ini terjadi dikarenakan pada molekulmolekul asam humat, terdapat gugus-gugus fungsional yang disebut kromofor yang bersifat menyerap sinar ultra violet dengan panjang gelombang lebih besar dari $180 \mathrm{~nm}$ dan memiliki elektron-elektron valensi (elektron ikatan) dengan energi eksitasi yang relatif rendah. Sehingga kemungkinan sinar ultra violet untuk dapat memberikan efek fotokimia bagi molekul organik dalam air akan semakin besar.

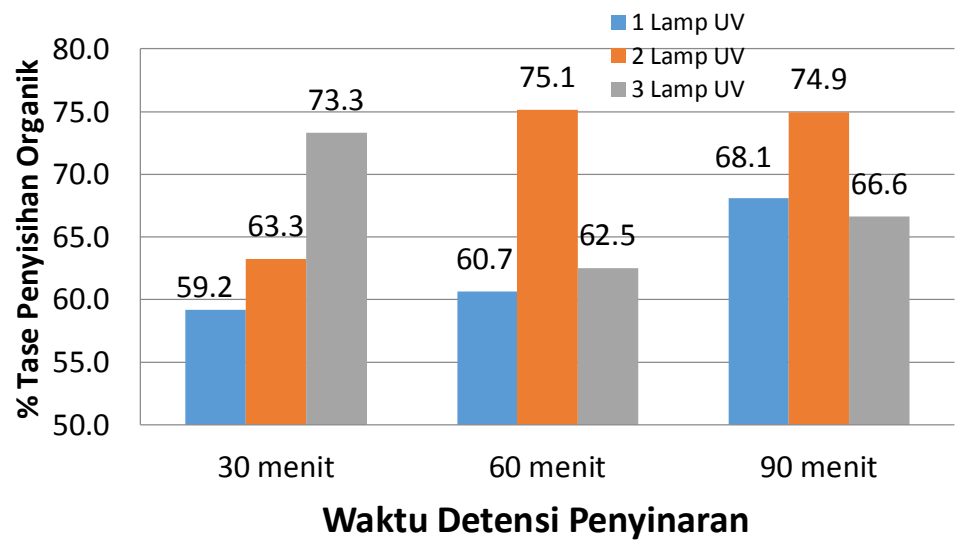

Gambar 2: Grafik Persentase Penyisihan Organik Berdasarkan Waktu Detensi

Pada prinsipnya hasil yang didapatkan dari percobaan ini menunjukan bahwa proses fotokimia dapat terjadi pada kandungan organik terlarut yang terdapat di dalam air gambut melalui penyinaran ultra violet sehingga kandungan organik dapat tersisihkan maksimal hingga $68 \%$ pada perlakuan 1 lampu UV (90 menit), 75\% pada perlakuan 2 lampu UV (60 menit) dan $73 \%$ pada 3 lampu UV (30 menit). Dapat kita lihat pada grafik persentase penyisihan organik di atas pada perlakuan 3 lampu UV terjadi fluktuasi yang cukup besar khususnya pada waktu detensi 60 menit dan 90 menit. Hal ini menunjukan 
bahwa adanya proses fotokimia di dalam reaktor UV yaitu reaksi-reaksi pemecahan ikatan-ikatan molekul organik kompleks di dalamnya. Menurut Juretic, et al (2015) menyatakan penambahan radiasi UV pada proses oksidasi dapat meningkatkan degradasi senyawa organik. Hal ini sejalan penelitian Elfiana (2012) menunjukan bahwa penyinaran sinar UV dapat menurunkan konsentrasi total senyawa organik atau menghasilkan satu molekul radikal hidroksil yang artinya bahwa terjadi proses fotokimia akibat penyinaran.

\section{Kesimpulan}

Dari hasil penelitian, dapat diambil kesimpulan bahwa proses penyinaran ultra violet dapat memberikan pengaruh penurunan kandungan organik dan intensitas warna air gambut. Efek variasi jumlah lampu UV dan waktu detensi terlihat nyata, dimana semakin bertambah jumlah lampu semakin cepat terjadinya reaksi fotokimia di dalam air baku, maka efesiensi penyisihan juga semakin besar. Penyisihan kandungan organik optimum terjadi pada penyinaran dengan 3 lampu UV 15 watt dan waktu detensi 30 menit baik pada pra pengolahan saja maupun dilanjutkan pada saringan pasir lambat.

\section{Daftar Pustaka}

Elfiana dan Zulfikar., 2012. Penurunan Konsentrasi Organik Air Gambut Secara AOP (Advanced Oxidation Processes) dengan Fotokimia Sinar UV dan UV-Peroksidasi. In: Seminar Nasional Yusuf Benseh, Menggali Potensi Daerah Untuk Percepatan Perluasan Pembangunan Ekonomi, Teknologi Dan Pendidikan. Lhokseumawe, Indonesia, 12-13 Desember 2012. SNYube: Lhokseumawe.

Fitria D., 2008. Penurunan Warna Dan Zat Organik Air Gambut Dengan Cara Two Staged Coagulation (Studi Kasus Air Gambut Riau). Institut Teknologi Bandung. Bandung.

Gmurek, M., Olak-Kucharcryk, M dan Ledakowicz, S., 2015. Journal of Environmental Health Science and Engineering. Influence of Dissolved Organic Matter in Natural and Simulated Water on the Photochemical Decomposition of Butylparaben. 13-28.

Han, S.K., Yamasaki, T., Yamada, K.I., 2016. Journal of Chemosphere. Photodecomposition of Tetrabromobisphenol A in Aqueous Humic Acid Suspension by Irridiation with Light of Various Wavelengths. 147(2016). pp,124-130.

Juretic, H., Smoljanic, G., dan Barta, M., 2015. The Holistic Approach to Environment. Degradation of Natural Organic Matter In Water by Using $\mathrm{UV}-\mathrm{C} / \mathrm{H}_{2} \mathrm{O}_{2}$ Process. 5 (3). pp,135-149.

Machbub, Badaruddin, Irianto., 1996.Prototip Intalasi Pengolahan Air Pusair Gambut-3. No. 15/KLTA-03/1996. Puslitbang Pengairan. Bandung.

Rafiq I., 1998. Pengolahan Air Gambut dengan Sinar Ultra Violet dan Saringan Pasir Lambat. Institut Teknologi Bandung. Bandung. 